\title{
Determinants of Youth Labour Absorption in Indonesia
}

\author{
Suryadia, Emi Syarief $^{\text {b }}$, Yuniarti Tri Suwadjic, Ardhian Kurniawatid, \\ Nurlia Rahmatika ${ }^{\mathrm{e}}$, ${ }^{\mathrm{a}, \mathrm{b}, \mathrm{c}, \mathrm{d}, \mathrm{e}}$ Puslitbang Ketenagakerjaan, Kementerian \\ Ketenagakerjaan, Jl. Jenderal Gatot Subroto Kavling 51
}

This study aims to determine how: the provincial minimum wage affects youth labour absorption in Indonesia; the regional economic conditions affect youth labour absorption in Indonesia; the level of education affects youth labour absorption in Indonesia; the effects of elderly people working on youth labour absorption in Indonesia; and the type of work elderly people do affects youth labour absorption in Indonesia. The data used in this study is secondary data from the Indonesian Central Bureau of Statistics (BPS), namely Sakernas of 2008-2018 with panel data type. Data was analysed using panel data regression analysis. The results show that several variables have a significant effect on employment opportunities for youth labour, namely the Provincial Minimum Wage (UMP), the Basic Education Level of Young Workers, the Secondary Education Level of Young Workers, and the Higher Education Level of Young Workers. These mean that there is no trade off between elderly and young workers. It could be because of the job positions in these two age groups are likely to be different, so that there is no positions' substitution for elderly and young workers, and the positions entered by these elderly workers are positions that require a fairly high work experience.

Key words: Youth, Elderly, Minimum Wage, Labour Absorption.

\section{Introduction}

One of the objectives of the Sustainable Development Goals (SDGs) is to settle youth and their roles in facing sustainable development. Youth development itself is addressed in Indonesia's strategic agenda in order to prepare a capable generation who will play a main role in the development era. The youth development nowadays is becoming increasingly important since the demographic bonus phenomenon that occurs in Indonesia is still predicted to continue for the next few years. Therefore, the manpower sector is one of the essential things in advancing the economy. The provision of sufficient employment opportunities is deemed necessary in 
order to keep pace with the increase of labour force entering the labour market. Thus, employment opportunities, quantity and quality of labour are very important indicators in economic development. It is because they have a decisive function in development, including: (1) labour as a resource for carrying out the production process and distribution of goods and services; and (2) labour as a target to develop the market.

One of the indicators in assessing the success of a country's development especially in the manpower sector is the number of job opportunities that are created. Job opportunities can be interpreted as a demand for labour force, or in other words, it can be defined as cooperation opportunities with the number of job vacancies available. Policy on employment opportunities itself consists of the efforts in encouraging the growth and expansion of employment opportunities in each region, as well as the development of the quantity and quality of available workforce. These policies are very important in order to take full advantage of the potential development in each region. The more development activities, the higher number of job opportunities available. Furthermore, these circumstances can boost the number of job opportunities for youth labour, and then can ultimately make the economy better.

The higher number of job opportunities available can provide opportunities for youth to get a job, so that they can meet the needs of their lives and their families. Ideally, the majority of the population working in the labour market are categorised productive age, namely in the age range 15 to 64 years. The youth and elderly population take part in the job market for some reasons, for example: they have responsibility to earn money for their living, to help the household or family economy, to pay the social needs, to face poor household conditions, and to get recognition from the community. The working population is differentiated based on age groups with the aim to see the contribution of youth labour, productive workers and older workers in the labour market. Youth labours are residents aged 15 to 24 years, while elderly labours are residents aged more than 60 years. Job opportunities for youth labours are influenced by several factors, such as wage levels, economic levels, education levels, and the number of elderly labours who are still actively working. Thus, if these factors change, this will affect the level of employment opportunities for youth.

Firstly, the wage rate can affects employment opportunities since the wage rate has a relationship with the demand and supply of labour. For companies, wages are seen as a burden, because the greater the level of wages, the smaller the proportion of profits gained by the company. Therefore, companies usually reduce the number of workers in response to an increase in the wage rate. On the other hand, the amount of labour absorbed is influenced by the real wage rate. Based on the labour demand theory, the quantity of labour demanded will decrease as a result of the increase in wages. If the wage level increases, while other inputs are constant, it means that the price of labour is relatively more expensive than other inputs. This situation encourages entrepreneurs to reduce the use of labour which is relatively expensive 
when compared to other inputs which are relatively cheaper in order to maintain the company maximum profit.

Secondly, changes in the regional economic conditions can result in some changes in job opportunities from time to time. In the economic concept, it is stated that the demand for labour is a derived demand from society's demand for goods and services in the economy. If the economy develops, the absorption of labour will also increase. Thus, economic growth is able to have a positive effect on job opportunities.

Thirdly, the level of youth labours' education is another factor that affects the level of employment opportunities for youth since people tend to think that education is a kind of investment. For those who have a high level of education, they will have more opportunities to get a job on the job market. Actually, the labour market can be classified into the educated labour market and the uneducated labour market. Those two forms of the labour market have some differences, for instance, educated workers generally have a higher work productivity than the uneducated, so that the worker's productivity is basically reflected in their level of education. In addition, in terms of time, the availability of educated manpower is obtained through the education and training process. On the other hand, for the filling vacancies process, companies need more time to select educated workers than uneducated workers.

Last but not least, the factor that affects the employment rate of youth labours is the number of elderly workers who are still actively working. In general, when elderly workers enter the labour market, there will be less job opportunities for youth labours. However, research conducted by Kalwij et al., (2010) found that the increasing number of elderly employment actually leads to more job opportunities for youth labours. The same result is found by the research conducted by Munnel and Wu (2012). Both found the facts that jobs for the elderly workers reduced youth unemployment, increased employment and created higher wages. These patterns are consistent for both men and women and also for groups with different levels of education.

Based on the explanation above, the problem formulations of this study are as follows: 1) How does the provincial minimum wage affects the youth labour absorption in Indonesia; 2) How does the regional economic conditions affect the youth labour absorption in Indonesia; 3) How does the level of education affects the youth labour absorption in Indonesia; 4) How is the effect of elderly workers, who still actively work, on the youth labour absorption in Indonesia; and 5) How does the type of work elderly labour do affects the absorption of youth labours in Indonesia?

In general, this study attempts to fill in the gaps of the impact of elderly labours on the absorption of youth labours in developing countries (especially in this case of Indonesia), while previous studies conducted in developed countries have only looked at the effect of an increase 
in the elderly workforce on employment opportunity for youth labours, regardless the effect of the work type undertaken by elderly labours on youth labours absorption in Indonesia. Types of work in this study means sector where the elderly labours work. The work types for the elderly are divided into three sectors, namely the agricultural, industrial and service sectors. The work type can affects the demand and supply of youth and elderly workers. In addition, the literature focussed on the relationship between youth and elderly labour force participation is also limited. A series of papers are only examining whether the number of employment for elderly people outreach the youth in 12 countries, including the United States, as in the study of Gruber and Milligan (2010). Based on individual and cross-country analyses, none of these international studies found evidence that an increasing number of elderly labour force participation reduces the youth employment opportunities. Indeed, evidence suggests that greater elderly labour force participation is associated with greater youth employment and reduced youth unemployment.

\section{Method}

The data used in this study is secondary data from the Indonesian Central Bureau of Statistics (BPS), namely Sakernas 2008-2018 with panel data type. According to Gujarati (2009), panel data is a combination of time series data and cross section data. Time series data is data from one object with several specific time periods, while cross section data is data obtained from one or more research objects in the same period. So that, this study utilises time series data for 10 years, from 2008-2018, while the cross section data in this study is 33 provinces in Indonesia.

The variables used in this study consist of dependent and independent variables. The variable that become the dependent variable is job opportunities for youth labours, while the independent variables used are Wages/UMP (X1), Gross Regional Domestic Product/GRDP (X2), Elderly Labours (X3), Youth Labours with basic education (X4), Youth Labours with secondary education (X5), Youth Labours in higher education (X6), Elderly Labours working in the agricultural sector (X7), Elderly Labours working in the industrial sector (X8), and Elderly Labours working in the service sector (X9) in Indonesia from 2008 to 2018.

In more details, the variables used in this study are as follows:

1. Employment opportunities for Youth Labours (Y) are approached by the number of working people aged 15 to 24 years.

2. The wage (X1) used in this study is defined as the Provincial Minimum Wage which is the lowest monthly wage consisting of the basic wage including a fixed allowance set by the regional governments of the provinces in Indonesia, the unit used in rupiah. 
3. GRDP (X2) is the total income or total expenditure in Indonesia on the output of goods and services produced by various sectors in each province in Indonesia for a period of one year. The GRDP in this study uses GRDP data based on constant prices, the unit used is trillion rupiah.

4. Elderly Labours (X3) are residents who work and are over 60 years old.

5. Youth Labours with basic education (X4) are residents aged 15-24 who work and have less than the same education as primary school.

6. Youth Labours with secondary education (X5) are residents aged 15-24 years who work and have a junior high school education.

7. Youth Labours with higher education (X6) are residents aged 15-24 who work and have a diploma or bachelor's degree.

8. Elderly Labours working in the agricultural sector (X7) are people over 60 years of age who work in the agricultural sector.

9. Elderly Labours working in the industrial sector (X8) are people over 60 years of age who work in the industrial sector.

10. Elderly Labours working in the service sector (X9) are residents over 60 years of age who work in the service sector.

This study uses panel data regression analysis. Data processing utilising Stata 13 software. This analysis is used because it involves a combination of cross section (33 provinces) and time series data of the last 10 years (2008-2018). If each cross section unit has the same number of time series observations, it is called a balanced panel, on the other hand, if the number of observations is different for each cross-sectional unit, it is called an unbalanced panel. According to Gujarati (2009) panel data has several advantages, for instance:

1. The combination of time series and cross section observations makes panel data provide more data, so that it can provide complete, more varied information and less collinearity between variables and is more efficient. In contrast, when it obtained a greater degree of freedom (df), so that the resulting estimate is better.

2. By combining information from time series and cross section data, it can solve problems that arise, because there are omitted variables.

3. Panel data is able to reduce collienerity between variables. 
International Journal of Innovation, Creativity and Change. www.ijicc.net

Volume 15, Issue 6, 2021

4. Panel data is better at detecting and measuring effects which simply cannot be done by pure time series data and more pure cross sections.

5. Panel data can test and build more complex behaviour models.

6. Panel data can lead to biases generated by individual aggregates due to the observed data;

7. Impacts that simply cannot be seen in pure cross section data or pure time series can be detected with panel data;

8. Panel data can make it easier to study complex behavioural models and also make data into thousands of units.

In the panel data model, there are three kinds of estimation approaches, namely pooled least squares, fixed effects and random effects. The pooled least squares approach simply combines all time-series and cross-sectional data and then estimates the model using the Ordinary Least Squares (OLS ) method, here the intercept is considered the same for all regions. The fixed effect approach reflects the difference in the intercept for time-series or cross-sectionals. Meanwhile, the random effect approach improves the efficiency of the least square process by taking into account the time-series or cross-sectional errors and there are also differences in the intercept.

Based on the research objectives above, to analyse the relationship between Wages/UMP (X1), Gross Regional Domestic Product/GRDP (X2), Elderly Labours (X3), Youth Labours with basic education (X4), Youth Labours with secondary education (X5), Youth Labours in higher education (X6), Elderly Labours working in the agricultural sector (X7), Elderly Labours working in the industrial sector (X8), Elderly Labours working in the service sector (X9) in Indonesia and the employment opportunities of youth labours, the panel data regression analysis model is:

$Y_{i t}=\alpha_{i t}+\beta_{1} X_{1 i t}+\beta_{2} X_{2 i t}+\beta_{3} X_{3 i t}+\beta_{4} X_{4 i t}+\beta_{5} X_{5 i t}+\beta_{6} X_{6 i t}+\beta_{7} X_{7 i t}+\beta_{8} X_{8 i t}+$ $\beta_{9} X_{9 i t}+\varepsilon_{i t}$

where:

$Y_{i t}=$ Number of working population aged 15 to 24 years (people)

$X_{1 i t}=$ Provincial Minimum Wage Rate (rupiah/month)

$X_{2 i t}=$ Gross Regional Domestic Product (rupiah/year)

$X_{3 i t}=$ Residents who work and are over 60 years old (person)

$X_{4 i t}=$ Population aged 15-24 years who work and have less than the same basic education (people)

$X_{5 i t}=$ Population aged 15-24 years who work and have a secondary education (people) 
$X_{6 i t}=$ Population aged 15-24 years who work and have higher education

$X_{7 i t}=$ Population over 60 years of age who work in the agricultural sector (people)

$X_{8 i t}=$ Population over 60 years old who work in the industrial sector (people)

$X_{9 i t}=$ Population over 60 years of age who work in the service sector (people)

$\alpha_{i t}=$ Constanta

$\varepsilon_{i t}=$ Error

$\mathrm{i}=$ Units for cross section (33 provinces)

$\mathrm{t}=$ unit untuk time series $(2008-2018)$

In panel data model analysis, there are three kinds of estimation approaches, namely:

a. Pooled Least Square (PLS) Approach

b. Fixed Effect Model (FEM) Approach

c. Random Effect Model (REM) Approach

The steps to determine the Panel Data Model include:

\section{a. Chow Test}

The chow test is used to determine whether the panel data regression technique with fixed effect (FE) is better than the common effect panel data regression (CE) model by looking at the residual sum squares. Testing is done by looking at the significance of the FE model through the $\mathrm{F}$ test statistic or also known as the Chow test.

\section{b. Hausman Test}

To determine which method should be used between the fixed effect or the random effect, the method developed by Hausman is used. The Hausman test is based on the fact that the use of dummy variables in the fixed effect and GLS methods is efficient while OLS is inefficient, on the other hand the alternative is that the OLS method is efficient and the GLS method is inefficient. Because the null hypothesis test is that the results of the two estimates are not different, the Hausman Test can be carried out based on the difference in these estimates. The Hausman test statistic follows a chi-square statistical distribution with a df of $\mathrm{k}$ where $\mathrm{k}$ is the number of independent variables. If the Hausman statistical value is greater than the critical value, then the correct model is the fixed effect model and vice versa.

\section{The Determination of the Best Model}

To find out the best model from the panel data model, several tests are needed. The test that needs to be done is to use the Chow test and the Hausman test. 
International Journal of Innovation, Creativity and Change. www.ijicc.net

Volume 15, Issue 6, 2021

\section{a. Chow Test}

The Chow test is used to select a model in panel data regression, namely between the FEM and PLS model. The hypothesis in this test is:

$$
\begin{aligned}
& H_{0}: \text { Model poolled least square } \\
& H_{1}: \text { Fixed effect Model }
\end{aligned}
$$

This test will be carried out by the $\mathrm{F}$ test statistic. $\mathrm{H}_{0}$ will be rejected if Prob $\mathrm{F}<0.05$, and vice versa.

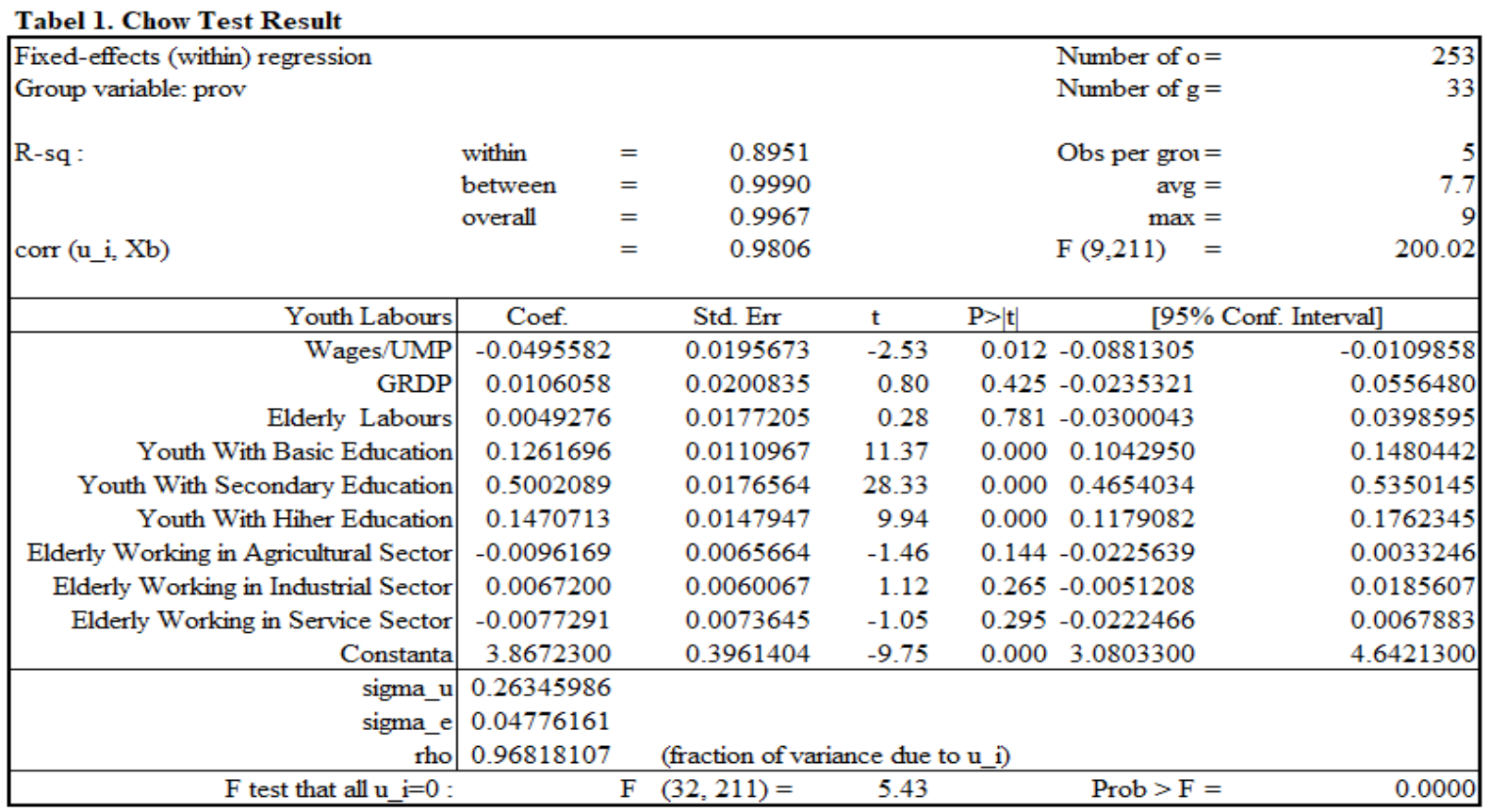

Source: Data (processed)

The Chow test is done by looking at the $\mathrm{F}$ test in order to make sure that the intercept of all individuals is 0 ( $F$ test that all $\left.u_{-} i=0\right)$. From Table 1 , it can be seen that prob $>F$ for this test $<0.05$. This shows that $\mathrm{H}_{0}$ for the chow test is rejected. From this test it can be concluded that the FEM is better than the PLS Model.

\section{b. Hausman Test}

The Hausman test is an advanced test in selecting a panel data regression model. This test is performed when the results shown by the Chow Test indicate that the FEM is better than other. The Hausman test will again choose which one is more suitable to be used either FEM or REM. The Hausman test uses the following hypothesis:

$$
\begin{aligned}
& H_{0}: \text { Random Effect Model } \\
& H_{1}: \text { Fixed effect Model }
\end{aligned}
$$


The statistic test used in those hypotheses is the chi-squared test based on Wald's criteria. If the Hausman test statistical value is greater than the critical value, $\mathrm{H}_{0}$ is rejected and the correct model is the FEM, and vice versa.

Tabel 2. Hausman Test Result

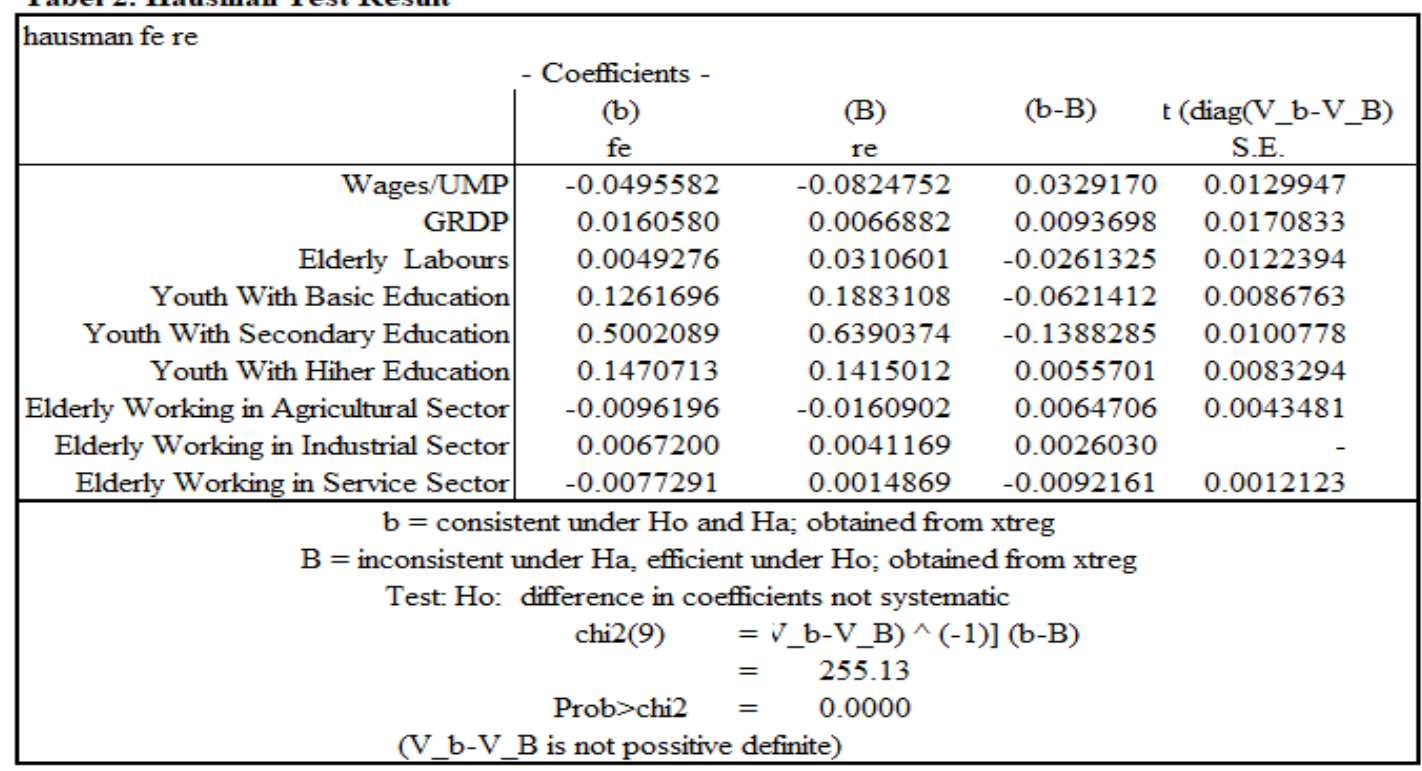

Source: Data (processed)

Table 2 shows the results of the Hausman test. From this Table, it can be seen that the value Prob $>\mathrm{chi}^{2}$ is less than $0.05 \%$, so it can be concluded that $\mathrm{H}_{0}$ is rejected. On the other words, the Fixed Effect Model is better than the Random Effect Model.

\section{Interpretation of the Results}

Some steps that have been taken above indicate that the best model that can be used to estimate the panel data used in this study is the Fixed Effect Model. This session will discuss in more details about the interpretation of the results obtained from the best model estimation. Table 3 shows the estimation results using the FEM. 
International Journal of Innovation, Creativity and Change. www.ijicc.net

Volume 15, Issue 6, 2021

\begin{tabular}{|c|c|c|}
\hline Variable & Koefisien & $P>|t|$ \\
\hline Dependen Variable: & Youth Labours & \\
\hline Wages/UMP & $-0,0495582 *$ & 0.012 \\
\hline GRDP & 0.01606 & 0.425 \\
\hline Elderly Labours & 0.00493 & 0.781 \\
\hline Youth With Basic Education & $0,1261696 * *$ & 0.000 \\
\hline Youth With Secondary Education & $0,5002089 * *$ & 0.000 \\
\hline Youth With Hiher Education & $0,1470713 * *$ & 0.000 \\
\hline Elderly Working in Agricultural Sector & -0.0096 & 0.144 \\
\hline Elderly Working in Industrial Sector & 0.00672 & 0.265 \\
\hline Elderly Working in Service Sector & -0.0077 & 0.295 \\
\hline Constanta & $=86123 * *$ & 0.000 \\
\hline Adj $R^{2}$ & 0.9967 & \\
\hline Observations & 253 & \\
\hline
\end{tabular}

Source: Data (processed)

From Table 3, it is known that the independent variable youth_basic youth_secondary and youth_higher significantly effect on youth_labours at alpha 5\%. These results are in line with the research conducted by Quintini (2011) that stated the transition of youth labour markets is generally highly correlated with levels of educational attainment. More briefly, in Table 3 we can see that the low, middle and high education levels of youth labours have an effect on the number of young people who work. The highest impact of the youth labours education level reached by secondary education level. Every $1 \%$ increase in the youth labours graduated from secondary education level will increase the number of working youth labours approximately about $50 \%$. Whilst, the smallest impact contribution of the youth labours educational level is reached by basic education level. It can be seen in the Table 3 that every $1 \%$ increase in youth workforce with basic education level will raise the number of working youth labours about $12.61 \%$.

According to this condition, the government needs to pay attention to the youth labours education. For instance, government can provide support and assistance in order to raise the youth labour education level. In addition, government can also provide training, apprenticeships and create jobs for youth labour. By improving the education level of youth labours, then it can improve their skills and certainly increase the value added and bargaining power of these youth labours. Furthermore, it is also necessary to establish an education system or curriculum that is in accordance with the needs of the market which is currently growing.

Several studies have highlighted the close relationship between labour market institutions, for example, recruitment policies, minimum wages and youth unemployment rates (Bertola \& Blau, 2007; Sanderson, 2019). The close relationship between the school system and the entry of the youth labour market is documented with great intensity. On the one hand, the public school system can influence the tendency of young people to leave school early, that is, to 
complete their education with a degree at the lower secondary level or below, with the consequence of experiencing more difficulties entering the labour market. On the other hand, the structure of post-mandated professional education choices has an impact on the youth labour market transition. In countries with well-established vocational education pathways or broad apprenticeship systems, youth who participate in vocational education tend to experience a faster entry into the labour market than they who graduated from general education (Hanushek et al., 2011; Riphahn \& Zibrowius, 2015). The reason for this faster entry is due to the increased short-term alignment of skills supply and demand. In particular, a mismatch of skills or qualifications is likely to reduce the quality and stability of jobs received initially, with potentially lasting negative impact on further labour market outcomes (Liu et al., 2012). At the same time, the phenomenon of increasing higher education (Quintini, 2007) may result in decreased opportunities for low-skilled workers to find work due to crowding-out. In addition, according to Quintini (2011), the Netherlands, Greece, Spain, Sweden, Luxembourg and Portugal are among the countries with the highest level of over-qualification.

From the partial test, it can be seen that the minimum wage (UMP) has an impact on the absorption of youth labours. By increasing the minimum wage, it can reduce the absorption of youth labours. The impact of UMP on youth unemployment ranks central in every UMP policy analysis. The theoretical basis claimed that UMP will have a negative impact on youth employment if it is forced to pay higher wages unlikely that employers will employ or lay off younger, unskilled and inexperienced workers. Therefore, in many countries, there is a subminimum wage for youth labours. Once set, the sub-minimum wage usually ranges from 60 to 80 percent of the total UMP. The effect of minimum wage on employment is widely debated in the literature. Marginean and Chenic (2013) find three possible debates and ways to organise a recent literature review on the effects of raising minimum wages: employment and unemployment effects; geographic, demographic and sectoral specificity; relationship with the business cycle.

Data on Gross Regional Domestic Product (GRDP), both at current prices and at constant prices, is an important indicator used to determine the economic condition of a region in a period. GRDP is the amount of added value generated by all business units in a particular area and can also be said to be the sum of the final (net) value of goods and services produced by all economic units. One of the visions of national development is to improve economic performance in order to be able to create jobs and organise a decent life for all people. The mission of development is to create a prosperous Indonesia with one of the main targets of reducing the number of poor people, knowing that much of the poverty has been reduced, it can also be seen how much the development carried out has led to changes in people's living conditions for the better and this is one of the development goals.

Understanding the relationship between economic growth and employment is an important task for policy makers (Manh et al., 2014). Indonesia's enormous economic potential must be 
realised in the form of high economic growth, which generates new jobs for the Indonesian population. The main problem facing the Indonesian economy is how development can be carried out while maintaining the stability of the economy that has been achieved. High and sustainable economic growth is the main condition or a necessity for the continuity of economic development. This study found a positive but insignificant GRDP impact on the absorption of young workers. Through legislation and regulations governments can strongly influence labour market adaptability (Scarpetta, 2014).

Apart from some of the variables previously described that affect the absorption of youth labours, there are other variables related to the elderly workforce. Talents, skills and experience possessed by elderly workers are a competitive advantage for companies, so that companies feel it is valuable to keep them working rather than replacing them with youth labours. From the estimation results using the Fixed Effect Model, it is known that working elderly labours have no impact on youth labours. This can be seen from the variable number of elderly labours which is not influenced statistically significant. From these facts, it is known that there is no trade off between elderly and youth labours. The number of working youth labours is not influenced by the number of working elderly labours. This could be occurs because the business sector for these two age groups is different. Apart from sectors, the fields of business between the elderly and young workers can also be different. Besides that, another possibility is that the positions between these two age groups are different.

For positions that require high work experience (professional, managerial, etc.), the tendency is not certainly a market share for youth labours. On the other hand, certain positions may only be filled by youth labours. Schawartz et al., (2018) show that elderly labours have opportunities that are largely untapped. Regarding to that research, only 18 percent of respondents said that age was seen as an advantage in their organisation. Employers can find great value in elderly labours abilities as mentors, coaches, experts or advisors. Therefore, the work experience and quality of workers will also increase with along with the length of time they work; this can then help to fill the talent gap in industries.

The scarcity of human resources with certain skills and knowledge often occurs in several industries. The solution is by utilising retired employees to be re-employed. The lack of key human resources in one division becomes an obstacle if the company is unable to find a replacement quickly. In the oil and gas industry, for example, there are not many human resources who are truly experts in their productive age. So that when employees retire the company organisation balancing is disturbed. In the end, the company will decide to re-recruit retired employees. All in all, government policies to empower the elderly labours still can be continued since there is no doubt that the entry of elderly labours in labour market will not create an adverse impact on youth labours as this study found. There should be proper utilization of experiences and expertise of old age people for the welfare of the society (Amiri, 2018). 


\section{Conclusion and Recommendation}

\section{Conclusion}

Based on the results and discussion in this study, it can be concluded as follows:

a. Several variables have a significant effect on employment opportunities for youth labours, namely the Provincial Minimum Wage (UMP), the Basic Education Level of youth labours, the Secondary Education Level of youth labours, and the Higher Education Level of youth labours.

b. GRDP has a positive but insignificant impact on the absorption of youth labours.

c. The low, middle and high education levels of youth labours affect the number of young people working. The highest impact of the education of young workers is on secondary education.

d. The presence of elderly workers has no effect on job opportunities for youth labours in Indonesia. This is evidenced by the existence of statistical results which show that the variable effect of the number of elderly people working is not significant. In other words, the re-entry of elderly people into labour market will not reduce the employment opportunities of youth labours. Even if there is an increase in elderly labours participation in the labour market, it will not negatively affect the employment of young people;

e. Some of the possibilities that lead to the absence of a trade off between elderly and youth labours are: job positions in these two age groups may be different so that there is no substitution of positions for elderly and youth labours; and the positions entered by these elderly labours are the positions which requires a fairly high work experience, for example a professional or managerial level. Therefore, surely it is not a market share for youth labours.

\section{Recommendations}

There are several recommendations from this study, namely:

a. There is a program needed for empowering the youth labours in order to create and develop productive economic enterprises, considering that not all of youth labours have work experience at the professional or managerial level (Amiri, 2018).

b. Support and assistance given to youth labours in increasing their education level is urgently needed. This can be done by providing job skills training and business assistance, apprenticeship, and by opening and creating jobs for young workers, especially those who still have education at the basic level.

c. Further research on this youth workforce is should be done to produce more details research that can boost employment opportunities toward Sustainable Development Goals (SDGs). 
International Journal of Innovation, Creativity and Change. www.ijicc.net

Volume 15, Issue 6, 2021

\section{Acknowledgement}

This work was supported by the Manpower Research and Development Center, Ministry of Manpower.

\section{REFERENCES}

Amiri, M. (2018). Problems Faced by Old Age People. The International Journal of Indian Psychology, Vol.6, Issue 3, 52-63.

Bertola, G., \& Blau, F. D. (Oktober 2007). Labor Market Institutions and Demographic Employment Patterns. Journal of Population Economics Vol. 20, No. 4 , 833-867.

Gruber, J., \& Milligan, K. (2010). Do Elderly Workers Substitute for Younger Workers in the United States?. In Social Security Programs and Retirement around the World: The Relationship to Youth Employment (pp. 345-360). University of Chicago Press.

Gujarati, D. N. (2009). Basic econometrics. Tata McGraw-Hill Education.

Hanushek, E. A., Woessmann, L., \& Zhang, L. (2011). General Education, Vocational Education, and Labor-Market Outcomes over the Life-Cycle. IZA DP No. 6083, 1-30.

Kalwij, A., Kapteyn, A., \& Vos, K. D. (2010). Retirement of Older Workers and Employment of The Young. De Economist, Vol.158, No.4, 341-359.

Liu, K., Salvanes, K. G., \& Sørensen, E. Ø. (2012). Good Skills in Bad Times: Cyclical Skill Mismatch and the Long-Term Effects of Graduating in a Recession. IZA DP No. 6820, $2-40$.

Manh, P. H., Ngoc, N. V., \& Dao, H. T. (2014). Relationship Between Economic Growth and Employment in Vietnam. JED, No.222, 40-50.

Munnell, A., \& Wu, A. (2013). Do older workers squeeze out younger workers?. Stanford Institute for Economic Policy Research Discussion Paper, (13-011).

Marginean, S., \& Chenic, A. S. (2013). Effects of Raising Minimum Wage: Theory, Evidence and Future Challenges. Procedia Economics and Finance, Vol.6, 96-102.

Quintini, G. (2011). Right for the Job: Over-Qualified or Under-Skilled? OECD Social, Employment and Migration Working. 
Quintini, G., Martin, J. P., \& Martin, S. (2007). The Changing Nature of the School-to-Work Transition Process in OECD Countries . IZA Discussion Paper No. 2582 , 1-25.

Riphahn, R. T., \& Zibrowius, M. (2015). Apprenticeship, Vocational Training and Early Labor Market Outcomes in East and West Germany. IZA DP No. 8901, 1-36.

Sanderson, E. (2018). Youth Transitions to Employment: Longitudinal Evidence From Marginalised Young People In England. Journal of Youth Studies, 1-20.

Schwartz, J., Monahan, K., Hatfield, S., \& Anderson, S. (2018). No Time to Retire : Redesigning Work for Our Aging Workforce. Touche Tomatsu Limited: Deloitte Insight.

Scarpetta, S. (2014). Employment Protection. IZA World of Labor, Vol.12, 1-10. 